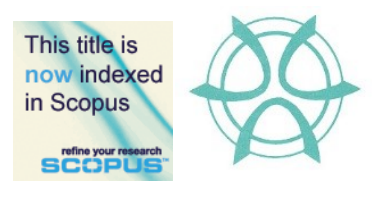

PLANNING MALAYSIA:

Journal of the Malaysian Institute of Planners

VOLUME 19 ISSUE 4 (2021), Page 23 - 35

\title{
IDENTIFICATION OF THE DEVELOPMENT CHARGES \\ EXEMPTION CRITERIA ON SUBDIVISION AND PARTITION FOR SMALL DEVELOPMENT APPLICATION ON AGRICULTURAL LAND
}

\author{
Azmi Rohani ${ }^{1}$, Robiah Suratman ${ }^{2}$, Durrishah Idrus $^{3}$ \\ ${ }^{1,2,3}$ Faculty of Built Environment and Surveying \\ UNIVERSITI TEKNOLOGI MALAYSIA
}

\begin{abstract}
In Malaysia, issues of the development charges imposition by the Local Planning Authority arises when it comes to a land conversion by means of surrender and re-alienation with the purpose of subdividing the land to family members. Therefore, this article aims to identify the exemption criteria of development charges for the subdivision and partition among family members by referencing its administration in Johor. The method used in this study is a face-to-face interview with six respondents from land administration and development practitioners. As a result, the criteria firmly stated that the development charges exemption will be applied for the purpose of a gift within the family members through the proof of direct linear relationship between the co-proprietors with particular conditions that shall be adhered to. Through this article, the development charges exemption execution may provide insights that can facilitate the co-proprietors and jurisdictions in Malaysia regarding multiple land ownership issues.
\end{abstract}

Keywords: development charges, land subdivision, non-development land, multiple land ownership, land administration, sustainable land management.

${ }^{2}$ Lecturer at Universiti Teknologi Malaysia. Email: robiah@utm.my 
Azmi Rohani, Robiah Suratman, Durrishah Idrus

Determination Method of Development Charges Exemption Criteria on Subdivision and Partition for Small

Scale Agricultural Land Application

\section{INTRODUCTION}

In general, development charges are fees imposed by the local planning authority on any approved project which amounts to the conversion of land used, i.e., if there are any changes of land use in the title, changes in land use zoning, changes in density, as well as changes in plot ratio (floor area). Basically, the main purpose of the development charges is to provide and improve infrastructures, public facilities and amenities, as well as the wellbeing of development areas (Rahman et al., 2017; Barton and Tsourou, 2000). Referring to the general term of the provision of development changes and with reference to Section 32 of the Town and Country Planning Act 1976 (Act 172), any land development which amounts to any increase in value because of change of land use is subject to development charges. However, the issues arise as to where the imposition of development charges is imposed by the local authority in most areas of land development, particularly in subdivision and partition. Therefore, an issue occurs as to what extent do these development charges apply to a land conversion by means of surrender and re-alienation, with the purpose of subdividing the land to family members. This study explores and analyses the significance of criteria identification in granting development charges exemption to overcome the issues and challenges of subdivisions and partitions of small-sized agricultural land for non-development and granting within family members purposes.

\section{RESEARCH BACKGROUND}

Difficulties in obtaining separate ownership of land that is owned by multiple masters or many owners has left the land abandoned and undeveloped. The difficulties in managing the land occurs when the owners often create disputes among themselves, and the situation becomes more difficult if the owners do not have any family relationships. Hence, the national land legislation has come up with an alternative for the landowners to either subdivide or partition their respective plots with the provisions under section 135 and section 140 in NLC 1965.

Subdivision in general refers to a situation where a piece of land is subdivided into a few lots where this subdivided lot will be registered with a separate individual title (Libbis and Lenshinky, 2006; Awang, 1997). It means, if one brings a registered proprietor or a piece of land and later by virtue of Section 135 - 139 National Land Code 1965 (NLC 1965) per se, or by virtue of Section 197 cross refer to Section 76 NLC 1965 by means of process of subdivision and variation of land use. There will be a few lots created based on these two processes in which every plot will still be registered under some registered proprietor. However, a conflict arises as to where the purpose of the subdivision is for family subdivision, but the proprietor will then be imposed with development charges by the Local Planning Authority. 
Given a situation where a piece of land at an acre intended to be subdivided to seven family members with the existing category of land use as agricultural, and the zoning in the local plan is for building. Procedurally, this application for subdivision would require an input from the planning authority and as the zoning differs from the land use category, this kind of subdivision per se would be rejected, unless and until it is submitted together with variation of land use. To have the piece of land subdivided and varied, the category of land use i.e., from agricultural to building, this kind of application would require a layout submission to the Local Planning Authority. The application which procedurally needs to be submitted through the One Stop Centre (OSC) at the Local Authority would then be subjected to certain requirements by a few technical agencies in which the issue regarding access Section 136(1)(h), requirement of Pre-Computation Plan Section 137(1) is required. As this application involves a variation of land use i.e., from agricultural to building (residential), therefore an imposition of development charges would be imposed.

Another issue to be discussed here is the requirement for approval of the planning authority in case of partition. No doubt, by virtue of election Section 141(1)(c), as in subdivision, the approval from the planning authority is required but to a certain extent, this planning authority has gone beyond by imposing a condition that the application of partition needs to be by planning permission submitted to the OSC, when in fact they should just get the plan for the partition endorsed.

In general, the law has clearly stated under Chapter 2 of Part Nine NLC 1965 that the co-proprietors of land held under a find title or a qualified title in continuation of find title, can have the land held by them partitioned so that every co-proprietor can have a separate title to themselves. Undoubtedly, it is subject to certain conditions imposed to ensure that the partition is done in an orderly manner to avoid any other consequences which may arise later. However, the spirit of partition is not a development in the first place. It is merely a process to terminate the co-proprietors registered under the same title.

In the case of partitions involving land with the category of agricultural held by a few co-proprietors, where the zoning in Local Plan is residential zone, and permissible area of each of the partition portions according to its original use (agricultural) is less than an acre each. Thereby, with the comment of approval from the local planning authority as required by Section 141(1)(c), would lead this application to be submitted through the planning permission by virtue of Section 22 of Act 172.

Records have shown that this kind of application is required to be applied together with the variation of land use and this is again, where the proprietors are traumatised by the expected development charges. This has 
Azmi Rohani, Robiah Suratman, Durrishah Idrus

Determination Method of Development Charges Exemption Criteria on Subdivision and Partition for Small

Scale Agricultural Land Application

resulted in the withdrawal of proprietors from continuing the submission of their application.

\section{LITERATURE REVIEW}

According to the Town and Country Planning Act 1976 (Act 172), all developments are obligated to obtain the approval of planning permission from the Local Planning Authority before any development activities may be conducted (Maidin and Ali, 2009; Othman, 2000). Three categories of development requires an application for planning permission, namely small development, medium development, and large development. Subdivision, partition, or amalgamation of land (agricultural land) which is less than 2 acres and does not involve any building or development activities fall into the small development category. Procedurally, for the purpose of subdivision or partition among the proprietors, they are required to apply for the approval of planning permission and will be imposed development charges in accordance with Subsection 32(1) of Act 172 as this application involves a variation of land use.

In Malaysia, imposition of the fees is determined by the Local Authorities, whereby the approved fees shall be gazetted as required by virtue of Section 35, Act 172. The amount of development charges may vary from one state to another, or even among the local authorities in the particular state. The determination of development charges is with respect to the changes of land use, the density changes, and the floor area changes which amount to the increase of value. The charges are charged based on the difference in the value of the land, before and after development. Table 1 below shows the difference in fees imposed by a few states:

Table 1: Percentages Imposition of Development Charges by State Authorities

\begin{tabular}{|c|c|c|c|c|c|c|}
\hline \multirow{3}{*}{ Side PBT } & \multicolumn{6}{|c|}{ States } \\
\hline & Selangor & Perak & Kelantan & Kedah & Pahang & Johor \\
\hline & \multicolumn{6}{|c|}{ Development Charge Rate (\%) } \\
\hline City Council & $30 \%$ & $10 \%$ & - & $20 \%$ & $20 \%$ & $25 \%$ \\
\hline $\begin{array}{l}\text { Municipal } \\
\text { Council }\end{array}$ & $30 \%$ & $10 \%$ & $15 \%$ & $20 \%$ & $15 \%$ & $15 \%$ \\
\hline $\begin{array}{l}\text { District } \\
\text { Council }\end{array}$ & $20 \%$ & $10 \%$ & $10 \%$ & $20 \%$ & $10 \%$ & $10 \%$ \\
\hline $\begin{array}{l}\text { International } \\
\text { Zone }\end{array}$ & & & & & & $30 \%$ \\
\hline
\end{tabular}

Procedurally, development charges will be imposed after the planning application has been approved by the Local Planning Authority in the process of planning permission approval as shown in Figure 1. Applicants may apply for development charges payment via instalment. If rejected, they shall pay the fees via one-off 
payment. Planning permission will be granted after the Local Planning Authority is satisfied with the first instalment payment pursuant with Subsection 22 (4)(b) of Act 172 .

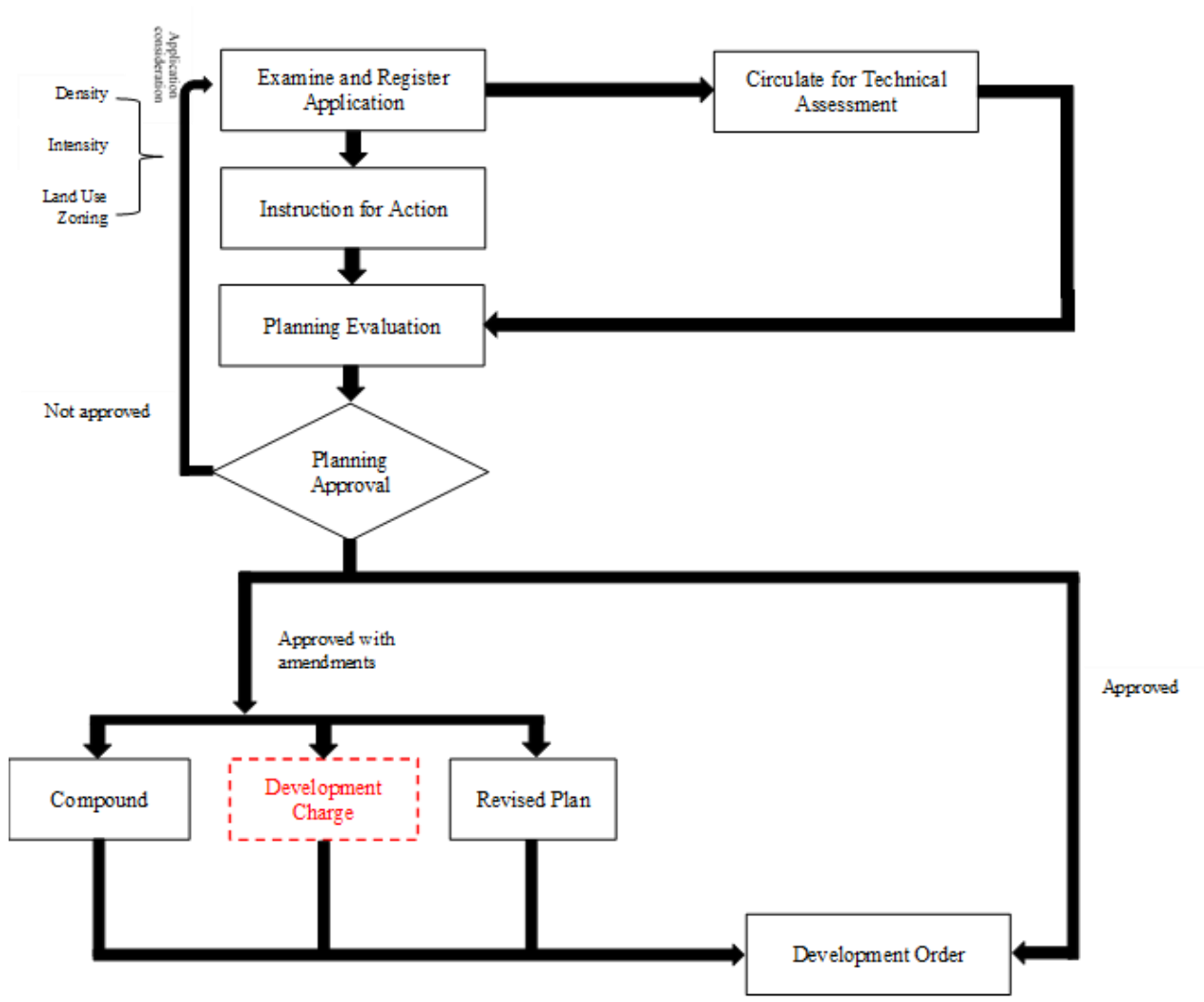

Figure 1: The Position of Development Charges Imposition in the Process of Planning Permission Approval (PLANMalaysia Johor, 2018)

Nevertheless, the State Authority may exempt the development charges that is non-profit in accordance with Subsection 32(3) of Act 172:

i) Development for welfare bodies' purposes by government agencies or non-governmental bodies (NGOs) registered;

ii) Welfare bodies and other organisations recognised by the government;

iii) Government buildings;

iv) Public stall buildings and food stalls;

v) Public religious projects; and

vi) Other development purposes approved by the State Authority. 
Azmi Rohani, Robiah Suratman, Durrishah Idrus

Determination Method of Development Charges Exemption Criteria on Subdivision and Partition for Small

Scale Agricultural Land Application

While the Local Planning Authority is the jurisdictive body to grant the planning permission approval, the State Authority is given the jurisdiction to approve subdivision and partition applications if the land applied for agricultural purposes with conditions: i) for subdivision - each partitioned lot is not less than $2 / 5$ hectares or an acre, meanwhile ii) for partition - the applied agricultural land must be less than $2 / 5$ hectares or an acre. The applications shall be made through Form 9A (Section 137) and 9B (Section 142) NLC 1965 respectively, and the State Authority will process the applications through surrender and re-alienation adherence.

\section{METHODOLOGY}

This study applied the qualitative method and Johor was selected as a case study. Primary data were collected via in-depth interviews consisting of six experts from land administration and development field, which two land administrators from Johor Land and Mines Office, a land administrator from Johor Bahru District Land Office, a land administrator from Kuala Lumpur Federal Territory Department of Lands and Mines, a land administrator from Negeri Sembilan Land and Mines Director Office and a representative from industry player. Interviews conducted on two land administrators from Kuala Lumpur and Negeri Sembilan are considerably important in regards of this new approach being introduced in land administration practice. Meanwhile, secondary data were collected from the analysis of the relevant statutes, rules, regulations, books, as well as related journals. This study specifically used data analysis, writing method through revision, and reading and listening to recording data collected during interviews. This study also initially analysed the interviewees' perceptions and insight regarding the criteria identification of development charges exemption on subdividing the land to acquire individual titles for nondevelopment purposes and grants within family members in the context of Johor.

\section{RESEARCH FINDINGS AND DISCUSSIONS \\ Criteria Identification for Development Charges Exemption on Subdivision and Partition}

Based on the interviewees' reviews and opinions, the results of discussions can be divided into four themes in determining the criteria for the exemption of development charges on subdivision and partition for non-development and granting to family members purposes. Table 2 summarises the discussions among the interviewees about the criteria's determination. 
Table 2: Summary of Interview Based on the Requirement of Development Charges Exemption on Subdivision and Partition Determination

\begin{tabular}{|c|c|}
\hline Theme & Discussions \\
\hline \multirow[t]{6}{*}{ Existing Practice } & $\begin{array}{l}\text { "...The common development charges benefit the developers to } \\
\text { gain the higher profit. In this context, family members will be } \\
\text { able to gain the profit." } \\
\text { (R1) }\end{array}$ \\
\hline & $\begin{array}{l}\text { "...However, if we subdivide the land using the common } \\
\text { method which is the agricultural land use will be converted into } \\
\text { residential land use, it will cause the agencies to disagree. Or if } \\
\text { it remains as the agricultural land, it will involve other aspects. } \\
\text { So, when the co-proprietors want to proceed the subdivision } \\
\text { with land conversion, by law, they will be charged with } \\
\text { development charges, even though there is no commercial } \\
\text { purpose in the process, and the co-proprietors simply just want } \\
\text { to get their registered divided plot, respectively. Therefore, state } \\
\text { authority took the initiative in introducing the exemption of } \\
\text { subdivision and partition within the family members to facilitate } \\
\text { the process." } \\
\text { (R2) }\end{array}$ \\
\hline & $\begin{array}{l}\text { "... In principle, the agricultural land use will remain unchanged } \\
\text { as it is, and because the size of the land is chronic, co-proprietors } \\
\text { shall go with the application of subdivision and partition } \\
\text { simultaneously, from agricultural land use converted to } \\
\text { residential land use." } \\
\text { (R3) }\end{array}$ \\
\hline & $\begin{array}{l}\text { "...The innovation of development charges exemption onto } \\
\text { agricultural land which is less than } 2 \text { acres for the purpose of } \\
\text { subdivision and partition provided by state authority is not } \\
\text { opposing the law. However, from the sight of a valuer, the } \\
\text { elements in determining the exemption shall not affect the value } \\
\text { of land i.e., land transaction or business or commercial land } \\
\text { development - these types of development should not be } \\
\text { exempted from being imposed development charges because it } \\
\text { will affect the value of properties in the future...In terms of } \\
\text { process, it is not opposing the law." } \\
\text { (R4) }\end{array}$ \\
\hline & $\begin{array}{l}\text { "...As far as I am concerned, state authorities in Malaysia } \\
\text { practice the common concept of development charges, which } \\
\text { means all land development application has to go through the } \\
\text { common process of planning permission because if not, it will } \\
\text { cause a higher royalty payment to the developers." } \\
\text { (R5) }\end{array}$ \\
\hline & $\begin{array}{l}\text { "...Under the circumstances that the proposed subdivision is } \\
\text { approved, the Land Administrator, or the State Director of }\end{array}$ \\
\hline
\end{tabular}


Azmi Rohani, Robiah Suratman, Durrishah Idrus

Determination Method of Development Charges Exemption Criteria on Subdivision and Partition for Small Scale Agricultural Land Application

Lands and Mines (PTG), or the State Authority shall consider the application and make appropriate decisions based on the merit of each application. If the application involves $2 / 5$ hectares of agricultural land or less, then the State Authority may approve it either without conditions and modifications, or reject as provided by section 143A NLC 1965 (2008 amendments)." (R6)

The issues

"...Johor Land Administration have found the solutions regarding the matter due to:

i) Many appeals involve subdivisions and partitions among family members; and

ii) The trend of subdivision and partition entry was declining because the co-proprietors knew they will be imposed development charges the moment they make the application."

(R1)

"...the issue that will arise in the future is once they want to build a house, they need to submit a planning permission because residential land use is subjected in preparing reports of side back, drainage facilities, road facilities - all accessibilities are required especially for the intermediate lots and behind the main road."

\section{(R4)}

“...This is the rationale of why NLC 1965 requires subdivision and partition to obtain the approval of planning authorities as per the conditions for approval of subdivision and partition under subsection 136(1) of mutatis mutandis with several modifications. However, the approval is not in the form of planning permission or planning order, because these two processes are not land development."

(R6)

Justification of the exemption

“...We want to encourage the prospect of land development in the future and assisting the co-proprietors and people of Johor in managing their respective land."

(R1)

“...The initiative has been taken because we have learnt what is happening to Kampung Baru. The reason why we came up with the solution was because we wanted to prevent subdivisions and partition's co-proprietorship elimination."

(R2)

“...We might lose the benefit of development charges, but the exemption will benefit the state and local authorities through 
other charges, which increase the value of land tax and property tax according to the subject matter."

“...The advantage of this exemption may benefit the coproprietors because the ownership of each subdivided plot is more apparent and proven..."

“...So, in my opinion, the innovation issued by the Johor Land Administration is one step ahead and is such a good approach to let the land grow and develop to the best use, rather than being abandoned. In addition, state and local authorities can collect the revenue on the developed land compared to the undeveloped agricultural land."

Solution

"...That is why the Johor Land Administration stated the conditions of subdivision and partition have to be within the circle of family members. How do you determine the circle of family members? Among the conditions are the applicant must gain the approval of family members' consent, letter of declaration, an endorsement in the registrar's caveat when registering the title, and no activities of sale and purchase within a certain period."

(R1)

“...So, how we are going to tie the development charges' exempted subdivision and partition land from being revoked? There are two arguments:

i) subdivision - if a sole landowner wants to divide his land up to ten partitions, then the new ten divided plots will be under the name of the sole landowner. So, in regard to preventing the plot from being sold, the verified names of the family members will be inserted in the registrar's caveat which will be released after the process of transferring ownership to the family members specified in the original application is completed.

ii) partition - the transactions of registered title for respective proprietors in computerised land system and the copy of original title, which is not disclosed in computerised land system, will be recorded as the proof of ownership."

(R3)

Based on the discussions above, the requirement of development charges exemption on subdivision and partition within family members were needed solely to facilitate the co-proprietors to get their respective divided plot and to prevent the elimination of co-proprietorship as well, so that they can manage and develop their respective land with their respective way, appropriately and legally. Besides, this development charges exemption also can prevent the land with 
Azmi Rohani, Robiah Suratman, Durrishah Idrus

Determination Method of Development Charges Exemption Criteria on Subdivision and Partition for Small

Scale Agricultural Land Application

multiple co-ownership being abandoned and poorly managed which state authorities alarmed that it may arises a diversity of string issues in the future. Therefore, to mitigate the issue between the requirement from planning authority and the interest of the public at large, who are not developers, a few conditions have been laid down so that the proprietors who are not developers can be exempted from the imposition of development charges.

\section{Requirement Conditions for Implementation of Subdivision and Partition Application Approval for Non-Development and to Family Members Purposes Based on Johor Land Administration Practice}

The application of subdivision and partition which requires the compliance to the zoning can be entertained and considered by the State Authority, either by complying to the prevision itself or by means of surrender and re-alienation. Surrender and re-alienation is a land development process which allows the process of variation of land use and subdivision to be done simultaneously. This is where the three processes, namely subdivision, partition, and variation of land use need to be submitted through planning permission application at the local planning authority and later proceed with the surrender and re-alienation.

With surrender and re-alienation, land officials either at the district land office or at the land and mines level would give recommendations to this application to determine that this application is purely for the purpose of subdividing to the family members, as well as terminating the co-proprietorship by means of partition. This means that the registered proprietors do not have to proceed with the process of variation of land zoning which would be timeconsuming and costly.

The process of subdivision per se, particularly subdivision to family members and partition shall be treated differently, either by its process or its prescribed fees. The process shall be less complex than a typical subdivision whereby the aspect of zoning classification compliance as in the local plan may need to be changed, rezoned, or up to the extent of distinguish with. Table 3 below highlighted the requirement conditions or criteria for the development charges exemption for particular subdivision and partition, which strictly executed for the purpose of non-development and as a gift or grant among family members.

Table 3: The Requirement Conditions of Execution for Development Charges Exemption on Subdivision and Partition for Non-Development and Within Family Members Purposes

\begin{tabular}{|c|c|c|}
\hline $\begin{array}{l}\text { Land Development } \\
\text { Process }\end{array}$ & & Conditions / Criteria \\
\hline Subdivision & i) & $\begin{array}{l}\text { A family subdivision is defined as division of a lot into a } \\
\text { few lots for the purpose of sale or a gift to a family }\end{array}$ \\
\hline
\end{tabular}


member, or members of the immediate family to the property owner.

ii) An immediate family member is defined as any person who is naturally or legally defined as a sibling, child, stepchild, grandchild, spouse, or parent of the property owner.

iii) Proof of kinship in the form of a birth certificate similar to a legal document is required before approval can be granted.

iv) A division of land solely among direct lineal descendants (parent to child only) and a direct lineal ascendant (child to parent only).

v) A lot created through this application is not eligible for sale to any other persons as the listed names of family members is endorsed together with the approval.

vi) A registrar caveat will be entered upon registration of the new subdivided title to ensure that compliance to condition is adhered with.

vii) A completed Statuary Declaration which states that:

- The subdivision is intended to keep the family estate within the family and not for the purpose of short-term investment. Therefore, the listed names of family members shall be as exhibit to the Statuary Declaration.

- Once a transfer is perfected or from the approval property owner to the listed names of family members, there will be a restrictive covenant on the subdivided property that would prohibit the transfer to a nonmember of the immediate family for a period of 10 years.

Partition

i) The co-proprietors shall establish that he has owned the property for at least 10 years prior to the application.

ii) The co-proprietors by transmission either by Small Estate Distribution order or court order, shall be exempted from complying with the duration of holding the ownership.

iii) The partitioned lot in general cannot exceed the number of co-proprietors as registered in the title. However, it is negotiable if there is a need for the partitioned lot to be more than the co-proprietors in the event of any road, river, and pipeline shown clearly in the plan.

iv) The partitioned lot can be less than the number of the coproprietors provided that the remaining co-proprietors agreed with the undivided portion in terms of areas, acreage, and locality which needs to be shown and signed on the partitioned land.

Source: Johor Land Administration, 2021 
Azmi Rohani, Robiah Suratman, Durrishah Idrus

Determination Method of Development Charges Exemption Criteria on Subdivision and Partition for Small

Scale Agricultural Land Application

From the discussions above, the conditions firmly stated that the development charges exemption for subdivision will be applied for the purpose of gift or sale within the family members only. This means, to ensure the process of granting the plots through subdivision can be exempted from being charged with development charges, the land owner(s) and the prospective subdivided plots owner(s), shall prove their direct linear relationship through legal support documents. In the other words, the exemption will not be applied if the subdivision purpose is involving the parties with indirect linear relationship, not to mention the non-relative's relationship. In the other hand, the development charges exemption for land partition only will be applied to the non-development purposes as it should complied with the variation of the agricultural land use. By law, the co-proprietors should have their own title deed for their portion of the land and commonly, the partitioned lots are allowed to exceed the number of coproprietors registered. Therefore, to ensure that no land partition process to the non-proprietors will occur in the future and the registered co-proprietors are able to manage and develop their own respective portion of the land, they shall proceed to submit the planning permission but this time, no development charges will be imposed. Through this exemption process, the co-proprietors can secure their ownerships as well as obtained the separate title deed.

\section{CONCLUSION}

Johor has come out with this development charge exemption approach after identified the issue of difficulties in obtaining the ownership of land that owned by many owners especially those cases related to family relationships. An exemption shall be appreciated in the case of land conversion to family members as well as a partition, either by the process of partition per se or partition with the variation of land use to compliment the requirement of land zoning. Hence, those highlighted conditions shall be adhered to for this purpose. This execution of development charges exemption for particular purpose will facilitate the application process of subdivision or partition in accordance with the NLC 1965 and moreover, as a solution to many abandoned or undeveloped land because of said circumstances.

\section{REFERENCES}

Awang, A. (1997). Land conversion, subdivision and amalgamation. Buletin Geoinformasi, 1(1), 37-44.

Barton, H. \& Tsourou, C. (2000). Healthy Urban Planning. London: Spon.

Johor Land Administration. (2021). Johor State Executive Council No. 218/2021.

Libbis, S., \& Leshinsky, R. (2006). Subdivisions with the Lot. Law Crest.

Maidin, A. J., \& Ali, B. B. M. (2009). Powers of the local authority in regulating land planning and development control: whither control. Planning Malaysia, 7(1).

National Land Code. (1965). Malaysia. 
Othman, H. A. (2000). Planning Requirements in Housing Development. Unpublished. PLANMalaysia Johor. (2018). Briefing on the Implementation of Methods of Development Charges in Johor.

Rahman, N. A. Y. A., Shaharudin, M., Ali, N., \& Pin, S. F. C. (2017). Implementation of Development Charge by Local Government of Malaysia: Implementation and challenges. Environment-Behaviour Proceedings Journal, 2(5), 459-467.

Town and Country Planning Act (Act 172). (1976). Malaysia.

Received: $19^{\text {th }}$ August 2021. Accepted: $10^{\text {th }}$ November 2021 